\title{
Accounting
}

\section{Factors affecting the application of social responsibility accounting}

\author{
Dinh The Hung ${ }^{a}$, Tran Trung Tuan ${ }^{a^{*}}$ and Nguyen Huu Anh ${ }^{b}$
}

${ }^{a} P h D .$, School of Accounting and Auditing, National Economics University, Hanoi, Vietnam

${ }^{b}$ Associate Professor, School of Accounting and Auditing, National Economics University, Hanoi, Vietnam

\begin{tabular}{l}
\hline C H R O N I C L E \\
\hline Article history: \\
Received March 22020 \\
Received in revised format March \\
202020 \\
Accepted March 242020 \\
Available online \\
March 24 2020 \\
\hline Keywords: \\
Business characteristics \\
Business operation \\
Social responsibility accounting \\
Vietnamese enterprises
\end{tabular}

Vietnamese enterprises

\section{A B S T R A C T}

\begin{abstract}
Vietnam is facing a lot of social problems such as excessive resources exploitation, social imbalance, threatened natural environment, etc. The majority of enterprises in Vietnam care about profits and they are blamed for harmful effects on the environment and society. Social responsibility accounting is applied as a tool which evaluates efforts to protect the environment and ensure the social stability of the businesses. Therefore, social responsibility accounting is essential to help administrators propose business strategies combining with environment conservation most appropriately. This research focuses on four factors affecting the application of the social responsibility accounting in Vietnamese enterprises. In this paper, SPSS 20 was used to collect and analysis data from Vietnamese enterprises. From this, recommendations can be given so that the enterprises can apply social responsibility accounting and promote it widely in Vietnam.
\end{abstract}

\section{Introduction}

Enterprises play an essential role in the economy and they are the central part of generating gross domestic product (GDP). Enterprises also need to set their sustainable development goals to be suitable for the trend of integration and sustainable development. Enterprises will be able to reach sustainable development through responsible activities to society like pollution control, waste recycling, compliance with environmental protection rules, and natural resources saving. Nevertheless, the main target of enterprises is profit, so for them, environment management not only is costly but also causes profit reduction. As the scale of production and business activities becomes larger, adverse impacts on environment increase. Social responsibility accounting (SRA) is a tool to measure necessary efforts to protect the environment and make sure the social stability of the enterprises. Therefore, SRA is essential to help administrators propose business strategies combining with environment conservation most appropriately. This research focuses on factors influencing the application of the SRA system into enterprises in Vietnam. From this, recommendations can be offered so that the enterprises can apply SRA and promote their use widely in Vietnam.

\section{Literature review}

Mathews's research (1993) indicated that SRA's mission is to declare the financial and non-financial information, qualitative and quantitative information of an organization. The declaration includes: Employment Report (ER); Human Resource

* Corresponding author. +84912843355

E-mail address: trungtuanktqd@gmail.com (T. T. Tuan) 
Accounting (HRA) and Environmental Accounting problems. Therefore, SRA's information serves a variety of users such as residents, labor, consumers, administrators of organizations. Pal et al. (2004) proposed an evaluating method which includes three sections: economy, environment and society. The research of Gholami et al. (2012) emphasized on corporate social responsibility (CSR) besides profitable targets since immoral actions could result in significantly severe consequences to the business activities of the enterprises. Therefore, SRA is known as the declaration of information about the effects of business activities in an organization on society and the environment for the people who care. Gray et al. $(1986,1987)$ defined SRA as a tool of information for measuring the effect of the economic activities of an organization on society and the environment for people interested in social. O'Dwyer (2006) described social and environmental accounting as a group of committed individuals responsible for the stakeholders. The SRA is considered as a technique for empowering the company's accountability and transparency to stakeholders outside the firm, addressing social, environmental and ethical issues, and the values of individuals with non - economic impact. The author reports that SRA could be considered as a science of observation, measurement, calculation, recording, processing and analyzing information about the responsibility of the enterprise such as the protection of the environment, ensuring the advantages of the consumer and the workers for ensuring the safety of the consumer and the workers. SRA can be also considered as a tool for building social goals through fully considering the requirements of the enterprise. Sustainability reporting guidance system is associated with Global Reporting Initiative (GRI) which has the superiority above the others, and many companies apply it since it collects information based on different objects. A shortage of technological facilities to construct the SRA reporting system creates trouble for the enterprises in implementing the SRA reporting system. Sabha and Shoubaki (2013) showed that: “(1) The experiences of auditors make no difference to the application of SRA into the company; (2) Pursuing CSR has positive effects on reputation, sustainable development and acceptance of society. (3) Restricting awareness and evaluating CSR bring in impediments in practicing Social Audit and SRA; (4) The legal regime affects SRA application; (5) Pursuing CSR depends significantly on the company's resources". Hoang Thuy Dieu Linh (2013) investigated on environmental financial accounting and the application of environment in Vietnam. The authors pointed out that the necessity of providing environmental information and identifying the components could be considered for environmental accounting. Tran Minh Phuong (2017) identified the factors that influence the application of SRA of enterprises in Vietnam including: (1) awareness of the usefulness of SRA; (2) the participation of the stakeholders; (3) the characteristics of the business; (4) social responsibility report; (5) the legal standards. In addition, the author has defined the extent of the influence of each factor to the application of SRA.

\section{Research Methodology}

\subsection{Research model}

After learning about the factors that influence the application of SRA in Vietnamese enterprises from previous studies, the research team believes that there are four factors: "Business characteristics", "The importance of social responsibility accounting", "Business operation" and "Legal framework" affect "Applying SRA in Vietnamese enterprises" to provide a linear regression equation describing the effect of the factors to the dependent variable has the form:

In which:

$$
A D=\beta_{0}+\beta_{1} D D+\beta_{2} Q T+\beta_{3} H D+\beta_{4} P L+e
$$

$A D$ : Application of SRA in Vietnamese enterprises $\quad D D:$ Business characteristics

$Q T$ : The importance of SRA $\quad H D$ : Business operation

$P L$ : Legal framework $\quad \beta_{1}, \beta_{2}, \beta_{3}, \beta_{4}$ : are the coefficients angle and $e$ is the error term

It can be synthesized into the research model as follows:

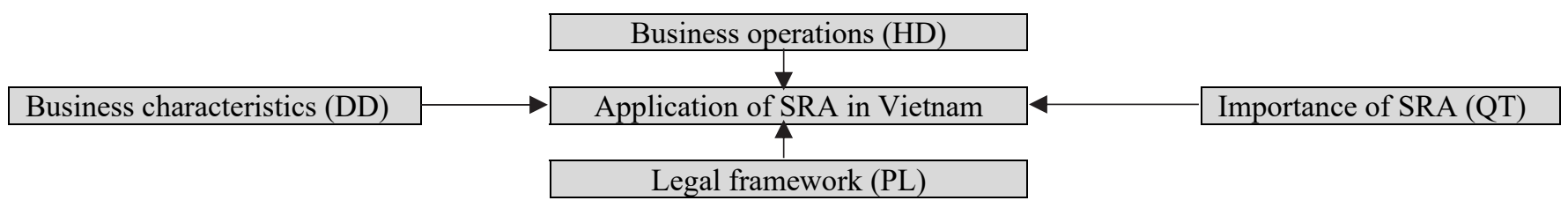

Fig. 1. Research framework for factors affecting Application of social responsibility accounting in Vietnamese enterprise

\section{Variables' measurement}

Regarding groups of factors affecting the application of SRA, some authors have presented the factors and corresponding evaluation criteria in their study. After the process of reference and selection, the researchers based some of the following reviews to determine the factors and criteria for assessing the level of impact. 
According to Trotman and Bradley (1981), Nguyen Thi Bich Lien (2017), Nguyen Thi Mai (2014) and Tran Minh Phuong (2017) Business characteristics affect the application of SRA. Specifically, the organization operating in the areas of using a lot of natural resources will have to pay more attention to SRA to protect the environment and quality of life.

\section{- The importance of social responsibility accounting}

Studies by Bebbington et al. (1994), Kuasirikun (2005), Zulkifli et al. (2009), Sabha and Shoubaki (2013) and Nguyen Thi Thu Hang (2017) have mentioned that SRA would play a vital role in the implementation and development of SRA in practice.

\section{- Business operation}

Tran Minh Phuong (2017), Nguyen Thi Bich Lien (2017), Nguyen Thi Mai Lien (2017) said that Business Operation is one of the factors affecting the application of SRA in enterprises.

\section{- Legal framework}

Legal framework is another factor given in the study of Tran Minh Phuong (2017) with the standard evaluation, for instance, standards of SRA; corporation between responsibility and social, political and economic situations.

\section{- The extent of Application of social responsibility accounting}

$\checkmark$ Implementing social responsibility accounting will improve the company's image (AD1): Pham Duc Hieu (2018) has affirmed: "By participating in social responsibility programs, the company can improve its image to customers and the public". When businesses launch programs and projects on social responsibility, businesses will create a good image and improve their brand.

$\checkmark$ Implementing social responsibility accounting will enhance business performance in the long term (AD2): According to Pham Duc Hieu (2018) the implementation of CSR will improve the financial performance of the company, which will bring the company long-term benefits. Bihari and Pradhan (2011) find that the CSR activities of banks have a positive impact on their business performance.

$\checkmark$ Implementing social responsibility accounting will advance the competitive advantages of companies (AD3): Pham Duc Hieu (2018) also pointed out: "Social responsibility will increase the company's competitive advantages". When causing negative impacts on the environment, the company will lose trust and credibility with consumers. Conversely, the application of social responsibility will help the company make a special impression to customers' awareness, which will increase the company's competitiveness.

$\checkmark$ Vietnamese companies need to implement social responsibility accounting by international practices for economic integration (AD4): Pham Duc Hieu (2018) stated: "Social responsibility and social responsibility reporting will become common practice in the future". In the future, CSR and CSR reporting are likely to become common practice. In order to integrate into the international economy, Vietnamese enterprises need to implement SRA in accordance with international practices.

$\checkmark$ Companies in Vietnam need to have a professional department in social responsibility accounting (AD5): According to Tran Minh Phuong (2017), "Enterprises in Vietnam need to have a specialized department of SRA of the enterprise accounting system". Each SRA unit is decentralized to manage, to control, direct and take responsibility for specific operations within its management decentralization. The "decentralization of management" creates a complex organizational structure that requires close supervision from superiors, so businesses need a specialized unit of SRA of the enterprise's accounting apparatus.

\section{Research hypotheses}

The factors of variables are measured by Likert scale with 5 levels: 1-Absolutely disagree, 2-Do not agree, 3- Neutral, 4- Agree, 5-Absolutely Agree.

- Hypothesis 1 (H1): Business characteristics have a positive influence on the application of SRA.

- Hypothesis 2 (H2): Awareness of the importance of SRA actively on the organization positive influences on the application of SRA.

- Hypothesis 3 (H3): The operation of business influences on the application of SRA in enterprises.

- Hypothesis 4 (H4): The legal procedures have a positive influence on the application of SRA in enterprises.

The study proposes the following influencing factors: 


\section{Table 1}

Summary of factors affecting the application of SRA in Vietnamese enterprise

\begin{tabular}{|c|c|c|}
\hline Variable & Evaluation criteria & Expected impact \\
\hline \multicolumn{3}{|l|}{ Independent } \\
\hline $\begin{array}{l}\text { Business } \\
\text { characteristics } \\
\text { (DD) }\end{array}$ & $\begin{array}{ll}\text { - } & \text { Business area (DD1); } \\
\text { - } & \text { Objectives of the organization (DD2); } \\
\text { - } & \text { Technological level (DD3); } \\
\text { - } & \text { Business scale (DD4) }\end{array}$ & + \\
\hline $\begin{array}{l}\text { The importance of } \\
\text { SRA } \\
(Q T)\end{array}$ & $\begin{array}{l}\text { - } \quad \text { The necessary of SRA for organization on the manager's view (QT1); } \\
\text { - } \quad \text { The vision of business strategy (QT2); } \\
\text { - } \quad \text { Knowledge and ability to proficiently use accounting software (QT3); } \\
\text { - } \quad \text { Training programs for specialized staff on SRA (QT4). }\end{array}$ & + \\
\hline $\begin{array}{c}\text { Business operation } \\
\text { (HD) }\end{array}$ & $\begin{array}{l}\text { - } \quad \text { Business age (HD1); } \\
\text { - } \quad \text { Plan of developing (HD2); } \\
\text { - } \quad \text { The ability of the company to provide information to related entities (HD3). }\end{array}$ & + \\
\hline $\begin{array}{l}\text { Legal framework } \\
\text { (PL) }\end{array}$ & $\begin{array}{ll}\text { - } & \text { Standards and principles of SRA (PL1); } \\
\text { - } & \text { Corporate responsibility (PL2); } \\
\text { - } & \text { Vietnamese's economic-political-social situation (PL3). }\end{array}$ & + \\
\hline \multicolumn{3}{|c|}{. } \\
\hline $\begin{array}{l}\text { Application of SRA } \\
\text { in Vietnamese } \\
\text { enterprise } \\
\text { (AD) }\end{array}$ & $\begin{array}{l}\text { - Implementing SRA will improve the company's image (AD1) } \\
\text { - Implementing SRA will enhance business performance in the long term (AD2); } \\
\text { - Implementing SRA will advance the competitive advantages of companies (AD3); } \\
\text { - Vietnamese companies need to implement SRA by international practices for } \\
\text { economic integration (AD4); } \\
\text { - Companies in Vietnam need to have a professional department in SRA (AD5). }\end{array}$ & \\
\hline
\end{tabular}

\section{Data collection and processing}

Apply quantitative research method with primary information. The research team collected data according to the survey below:

- The subject of the study: Administrators at all levels of enterprises, accounting experts, and university lecturers.

- Survey sample: Takes according to the convenient sampling method. The total number of questionnaires issued was 150 , and the total votes were 106 votes. After removing 50 invalid votes, valid votes are 56 votes.

- Survey: The poll was based on the 5-point Likert scale. The surveyors are asked to answer by choosing one of the answers: 1Absolutely disagree, 2 - Do not agree, 3 - Neutral, 4- Agree, 5-Absolutely agree. Answers will be assigned values between 1 and 5 when analyzing data. The content of the questionnaire consists of 2 parts: the first part is the general information about the object to be surveyed and the second part is the questions related to the level of influence of factors on the application of SRA at the Vietnamese company. The survey process: consists of 2 steps: Step 1, test to check the accuracy of the questionnaire. Step 2, survey officially to gather information about the influence of factors on the application of SRA in Vietnamese enterprises and find the most influential factor. The investigated data will be processed and analyzed quantitatively by using multivariate statistical analysis tools and the support of SPSS software 20 with the following specific steps: Descriptive statistics analysis, Exploratory Factor Analysis, Reliability analysis and Regression analysis

\section{The research Results and Discussion}

\section{Descriptive statistics analysis}

The results of running SPSS for variables represent in Table 2. From Table 2, the results of descriptive statistics show that the variables have a standard deviation less than 1, so options respondents selected are relatively identical while norms belonging to variable "Business operation" are less identical than the others (standard deviation more than 1). 
Table 2

Results of descriptive statistics analysis

\begin{tabular}{|c|c|c|c|c|}
\hline Variable & Minimum & Maximum & Mean & Standard Deviation \\
\hline DD 1 & 1.00 & 5.00 & 3.6724 & 0.99803 \\
\hline DD 2 & 1.00 & 5.00 & 3.7414 & 0.94238 \\
\hline DD 3 & 1.00 & 5.00 & 3.7759 & 0.89429 \\
\hline DD 4 & 1.00 & 5.00 & 3.6552 & 0.86629 \\
\hline QT 1 & 1.00 & 5.00 & 3.7586 & 0.80154 \\
\hline QT 2 & 1.00 & 5.00 & 3.7586 & 0.94238 \\
\hline QT 3 & 1.00 & 5.00 & 3.7241 & 0.89429 \\
\hline QT 4 & 1.00 & 5.00 & 3.6724 & 0.86629 \\
\hline HD 1 & 1.00 & 5.00 & 2.6207 & 1.36147 \\
\hline HD 2 & 1.00 & 5.00 & 2.4828 & 1.23176 \\
\hline HD 3 & 1.00 & 5.00 & 3.1552 & 1.08905 \\
\hline PL 1 & 1.00 & 5.00 & 3.7241 & 0.79014 \\
\hline PL 2 & 1.00 & 5.00 & 3.7759 & 0.85928 \\
\hline PL 3 & 1.00 & 5.00 & 3.9138 & 0.82259 \\
\hline AD 1 & 1.00 & 5.00 & 3.5345 & 0.95908 \\
\hline AD 2 & 1.00 & 5.00 & 3.9828 & 0.80549 \\
\hline AD 3 & 1.00 & 5.00 & 3.7414 & 0.80699 \\
\hline $\mathrm{AD} 4$ & 1.00 & 5.00 & 4.0517 & 0.82552 \\
\hline AD 5 & 1.00 & 5.00 & 3.3621 & 1.13475 \\
\hline
\end{tabular}

\section{Reliability analysis}

After the data is collected, the research group tests the reliability of the data:

\section{Table 3}

Results of Cronbach's Alpha coefficient test

\begin{tabular}{|c|c|c|}
\hline Variables & $\begin{array}{c}\text { Corrected Item - Total } \\
\text { correlation }\end{array}$ & Cronbach's Alpha if item deleted \\
\hline \multicolumn{3}{|l|}{ Independent variable "Business characteristics" } \\
\hline DD1 & 0.766 & 0.817 \\
\hline$\alpha=0.870 \cdot N=4$ & 0.786 & 0.809 \\
\hline$\alpha=0.870 ; N=4$ & 0.704 & 0.844 \\
\hline DD4 & 0.656 & 0.860 \\
\hline \multicolumn{3}{|l|}{ Independent variable "The importance of SRA" } \\
\hline QT1 & 0.597 & 0.749 \\
\hline$\alpha=0.795 ; N=4$ & 0.620 & 0.737 \\
\hline QT3 & 0.645 & 0.723 \\
\hline QT4 & 0.563 & 0.764 \\
\hline \multicolumn{3}{|l|}{ Independent variable "Business operation" } \\
\hline HD1 & 0.795 & 0.784 \\
\hline$\alpha=0.871 ; N=3$ & 0.869 & 0.707 \\
\hline HD3 & 0.624 & 0.925 \\
\hline \multicolumn{3}{|l|}{ Independent variable "Legal framework" } \\
\hline PL1 & 0.743 & 0.782 \\
\hline$\alpha=0.854 ; N=3$ & 0.726 & 0.798 \\
\hline PL3 & 0.712 & 0.810 \\
\hline \multicolumn{3}{|c|}{ The dependent variable "Application of SRA in Vietnamese enterprise" } \\
\hline AD1 & 0.676 & 0.821 \\
\hline AD2 & 0.747 & 0.806 \\
\hline$\alpha=0.854 ; N=5$ & 0.663 & 0.826 \\
\hline AD4 & 0.684 & 0.820 \\
\hline AD5 & 0.623 & 0.846 \\
\hline
\end{tabular}

* $\alpha$ is Cronbach's Alpha coefficient, $N$ is the number of observed variables of each factor

(Source: results of running SPSS 20)

Through the data is contained in table 3, we can see that the element scales analyzed in the research model are confident and appropriate. However, Cronbach's Alpha, if business operation 3 is deleted, is 0.925 that is more than corrected Item - Total correlation. Therefore, the research group considers removing this variable out of the model.

Analyzing the correlation between variables

To consider the relationship between factors which influence on the application of SRA, research group uses Pearson correlation coefficient and analyses the correlation to obtain the following result: 


\section{Table 4}

Results of correlation analysis

\begin{tabular}{|c|c|c|c|c|c|c|}
\hline & & DD & QT & HD & $\mathrm{PL}$ & $\mathrm{AD}$ \\
\hline \multirow{2}{*}{ DD } & Pearson Correlation & 1 & 0.000 & 0.000 & 0.000 & 0.532 \\
\hline & Sig. (2-tailed) & & 1.000 & 1.000 & 1.000 & 0.000 \\
\hline \multirow{2}{*}{ QT } & Pearson Correlation & & 1 & 0.000 & 0.000 & 0.473 \\
\hline & Sig. (2-tailed) & & & 1.000 & 1.000 & 0.000 \\
\hline \multirow{2}{*}{ HD } & Pearson Correlation & & & 1 & 0.000 & 0.153 \\
\hline & Sig. (2-tailed) & & & & 1.000 & 0.252 \\
\hline \multirow{2}{*}{ PL } & Pearson Correlation & & & & 1 & 0.391 \\
\hline & Sig. (2-tailed) & & & & & 0.002 \\
\hline $\mathrm{AD}$ & $\begin{array}{l}\text { Pearson Correlation } \\
\text { Sig. (2-tailed) }\end{array}$ & & & & & 1 \\
\hline
\end{tabular}

The findings in this table show the relationship between the dependent variable and the independent one is in the same dimension because of the correlation coefficient $r>0$. In general, the $P_{-}$value of independent variables equals 1.00 which means that not affecting each other, and this value between independent and dependent variables ultimately equals 0.00 ( $<0.05$ : statistical significance). However, the $\mathrm{P}$ _value of $\mathrm{DD}$ and $\mathrm{AD}$ variable is $0.252(>0.05)$, so this independent variable is removed out of research model due to not influencing on the dependent variable.

\section{Variance analysis}

After analyzing correlation, the research group analyses ANOVA variance, and the results are provided in the Table 5 as follows,

\section{Table 5}

Results of ANOVA analysis

\begin{tabular}{llccccr}
\hline & Model & Sum of square & df & Mean square & F & Level of significance \\
\hline \multirow{3}{*}{1} & Regression & 38.638 & 3 & 12.879 & 37.876 & 0.000 \\
& Residual & 18.362 & 54 & 0.340 & & \\
\cline { 2 - 7 } & Total & 57.000 & 57 & & \\
\hline
\end{tabular}

(Source: results of running SPSS 20)

From the data is showed in the table above, we can see a level of significance $0.00<0.05$. Therefore, it is reliable that the independent variables "Business characteristics", "The importance of SRA", "Legal framework" are different to "Application of SRA in Vietnamese enterprise".

\section{Regression model analysis}

The result of regression exposes in Table 6:

\section{Table 6}

Results of regression

\begin{tabular}{|c|c|c|c|c|c|c|c|}
\hline Model & B & Standard Error & $\begin{array}{c}\text { Standardized Coefficients } \\
\text { Beta } \\
\end{array}$ & $\mathrm{t}$ & Sig. & Tolerance & VIF \\
\hline Constant & -4.862 & 0.475 & & -10.224 & 0.000 & & \\
\hline QT & 0.433 & 0.144 & 0.299 & 3.001 & 0.004 & 0.601 & 1.664 \\
\hline DD & 0.555 & 0.130 & 0.438 & 4.261 & 0.000 & 0.564 & 1.772 \\
\hline PL & 0.312 & 0.146 & 0.226 & 2.138 & 0.037 & 0.533 & 1.875 \\
\hline
\end{tabular}

Adjusted R Square $=0.660$ Durbin-Watson value $=1.991$ Dependent variable: AD

(Source: results of running SPSS 20)

Results of regression demonstrate that all variables in research model (not even constant) have level of significance (Sig value $<0.05)$. This means that research hypothesizes are accepted with $95 \%$ reliability.

Adjusted $\mathrm{R}^{2}$ value equals $0.66>0.1$, which is acceptable and shows that independent variables in research model only explain $66 \%$ for the change of dependent variable, the other percent is expounded by the factors out of the model.

Recurrent equation is defined:

$$
A D=-4.862+0.555 \times D D+0.433 \times Q T+0.312 \times P L
$$

The regression equation and the estimated results show the "Business characteristics"- (DD) has the most significant effect on 
using SRA with the regression coefficient is 0.555 . That also means the features of the organization has the most positive effects on using SRA. Depending on the characteristics of each corporation, the level of applying SRA is different to ensure the sustainable development goals of corporation. The second factor is "The Importance of SRA" - QT whose regression coefficient is 0.433 . It shows that the role of SRA has a positive influence on using SRA in enterprises. If the management is more aware of the importance of SRA, implement SRA in enterprises is more necessary. Lastly, the "Legal framework" - PL, the regression coefficient is 0.312 has the least effect. If the legal system and judicial administration are more stringent, the user level will increase. However, this is forced by the provisions of the law, so it is not highly effective (regression coefficient is the smallest). Therefore, it can be said that to increase the level of application of SRA, the impact of enterprise features brings the highest efficiency. Conclusion for hypothesis: Business characteristics, The Importance of SRA, and the Legal framework has a positive impact on applying SRA in Vietnamese enterprises. According to the correlation analysis between independent variables and dependent variables, Business operation does not affect the application of SRA, and it was removed from the regression model. Thus, H3 is rejected.

\section{Conclusion}

During the past two decades, there have been tremendous efforts to take care of environment through SRA efforts. Managers need to change their perception of SRA, improve their knowledge of SRA to meet the requirements of providing information not only quickly but also accurately on SRA. Understanding that, managers will be more proactive in applying SRA to the company's operations. It is necessary to clearly define the responsibilities of state management agencies and related entities, generally in policy making, information, propaganda, inspection, and handling of violations of enterprises, which are related to social responsibility and responsibility for the market, consumers and environmental protection in particular. Coordination between state management agencies and other related entities also plays an essential role since SRA only becomes urgent when there is a synchronous monitoring mechanism, a combination of government and local forces in society, especially associations, the media and newspapers. Government agencies and organizations should have a close combination. The government should provide regulations on SRA, social information, and environmental information to ensure consistency in the management of social responsibility. Besides, it must be stronger in the introduction of SRA to increase awareness, actions of organizations, parties involved in social and environmental issues in each enterprise, and the entire economy.

\section{References}

Bebbington, J., Gray, R., Thomson, I., \& Walters, D. (1994). Accountants' attitudes and environmentally-sensitive accounting. Accounting and business research, 24(94), 109-120.

Gray, R., Owen, D., \& Adams, C. (1996). Accounting \& accountability: changes and challenges in corporate social and environmental reporting. Prentice Hall.

Gray, R., Owen, D., \& Maunders, K. (1987). Corporate social reporting: Accounting and accountability. Prentice-Hall International.

Kuasirikun, N. (2005). Attitudes to the development and implementation of social and environmental accounting in Thailand. Critical Perspectives on Accounting, 16(8), 1035-1057.

Gholami, S., Parvizi, M., TamriNeia, A., Nemati, S., Abgineh, M., \& Emami, M. (2012). Social Responsibility Accounting: From Theory to Practice. Journal of Basic and Applied Scientific Research, 2(10), 10111-10117.

Le Kim Ngoc (2016). Accounting of corporate social responsibility. Journal of Accounting \& Auditing, 4, 151.

Mathews, M. R. (1993). Socially responsible accounting. CRC Press.

Mathews, M. R. (1997). Twenty-five years of social and environmental accounting research. Accounting, Auditing \& Accountability Journal, 10(4), 481-531.

Ministry of the Environment (1999). Environmental Accounting Guidelines.

Nguyen Huu Phu (2014). Organize responsibility accounting in the construction corporations under the Ministry of Transport. Phd Thesis. Academy of Financial.

Nguyen Thi Bich Lien (2017). Small and medium-sized enterprises development in supporting industry”, PhD thesis, Graduate Academy of Social Sciences, Vietnam Academy of Social Sciences

Pal, N., Sundaresan, S., Ray, J., Bhargava, H., Glantz, E., \& McHugh, M. W. (2004). Knowledge Quotient ${ }^{\mathrm{TM}}(\mathrm{KQ})$ : A Way to Measure the Knowledge Intensity of Your Team.

O’Dwyer, B. (2006). Theoretical and practical contributions of social accounting to corporate social responsibility. Corporate social responsibility, 1, 123-148.

Pham Duc Hieu (2018). Factors affecting the implementation and reporting of corporate social responsibility of Vietnamese enterprises. Journal of Economic Development, 246.

Pham Van Duoc (2010). Organize the accounting reporting system to assess the division of responsibilities in commercial enterprises in Vietnam, University of Economics Ho Chi Minh city. 
604

Sabha, S. A., \& Shoubaki, Y. (2013). The importance of implementing Social Responsibility Accounting (SRA) in public shareholding companiesin Jordanand its impacton their sustainability. International Journal of Business and Social Science, 4(6).

Tran Minh Phuong (2017). Factors affecting the implementation of Social Responsibility Accounting in enterprises in Vietnam. Master Thesis, University of Economics Ho Chi Minh city.

Trotman, K. T., \& Bradley, G. W. (1981). Associations between social responsibility disclosure and characteristics of companies. Accounting, Organizations and Society, 6(4), 355-362.

Zulkifli, N., Telford, B., \& Marriott, N. (2009). Social and environmental accounting in Malaysia: practitioners' views.'. Research in Accounting in Emerging Economies, 9, 145-167.

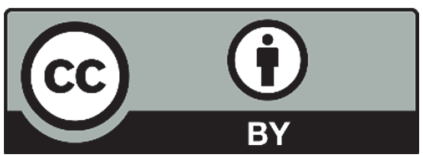

(C) 2020 by the authors; licensee Growing Science, Canada. This is an open access article distributed under the terms and conditions of the Creative Commons Attribution (CC-BY) license (http://creativecommons.org/licenses/by/4.0/). 